UDK 678.023.5

DOI: 10.31891/CSIT-2020-1-2

SYNYUK O.

Khmelnitsky National University

\title{
NUMERICAL SIMULATION OF VISCOPRELIC LIQUID FLOW WITH INTEGRAL RHEOLOGICAL LAW IN FLAT OR CYLINDRICAL CHANNELS
}

The viscoelastic liquid may be a melt of a polymeric material from a rheological point of view. Therefore, emphasis will place on the practical application of the results of the solution of the mathematical model of the flow of viscoelastic fluid in the study of the process of filling the cavity of the mold with polymeric material.

High shear stresses can occur in flat or cylindrical channels. During the flow of viscoelastic fluid, in which the carbon bonds of macromolecules are broken, which leads to a decrease in the average molecular weight, and this leads to a change in molecular weight distribution, which significantly reduces the performance product. Therefore, it is important, in our opinion, to create a method for determining the stress field that arises in the process of forming products.

The article is devoted to the development of a mathematical model of the flow of viscoelastic fluid in flat or cylindrical channels and its implementation by numerical methods. The calculation of this model will allow to determine the stress field in the middle of the viscoelastic fluid during its movement in flat or cylindrical channels under certain initial and boundary conditions.

The paper proposes to introduce the concept of "memory" into the model and to assume that the stress determined by the complete history of polymer deformation. This assumption allowed us to express the stress tensor as an isotropic functional of the deformation history.

To solve the developed numerical model of viscoelastic fluid flow with integrated rheological law, a procedure for calculating its finite difference method proposed.

Numerical mathematical model of viscoelastic fluid in its implementation by the finite difference method (MAC method) allows determine the stress field in the middle of the entire flow region.

The results of this modeling can used in the development of injection molding equipment and improvement of equipment for injection molding of polymer products.

Keywords: viscoelastic fluid flow, polymer, mathematical model, integral rheological law, stress tensor, memory function, numerical integration, quadratic interpolation, finite-difference method, marker and cell method.

СИНЮК О. М

Хмельницький національний університет

\section{ЧИСЕЛЬНЕ МОДЕЛЮВАННЯ ТЕЧІЇ В'ЯЗКОПРУЖНОЇ РІДИНИ З ІНТЕГРАЛЬНИМ РЕОЛОГІЧНИМ ЗАКОНОМ У ПЛОСКОМУ АБО ЦИЛІНДРИЧНОМУ КАНАЛАХ}

Стаття присвячена розробці математичної моделі течії в'язкопружної рідини в плоскому або циліндричному каналах та реалізації їі чисельними методами. Розрахунок цієї моделі при певних початкових і граничних умовах дозволить визначати поле напружень в середині в'язкопружної рідини під час ї̈ руху в плоскому або циліндричному каналах.

У роботі запропоновано ввести в модель поняття «пам'яті» і припустити, що напруження визначається повною історією деформації полімеру. Це припущення дозволило виразити тензор напруження як ізотропний функціонал передісторії деформації.

Для розв'язку розробленої чисельної моделі течії в'язкопружної рідини з інтегральним реологічним законом запропонована процедура розрахунку ї̈ методом кінцевих різниць.

Розглянута в статті чисельна математична модель в'язкопружної рідини при реалізації ї̈ методом кінцевих різниць (метод мАС) дозволяє визначити поле напружень в середині всій області течї̈.

Результати даного моделювання можна використовувати при розробці литтєої оснастки та вдосконалення обладнання для лиття полімерних виробів під тиском.

Ключові слова: течія в'язкопружної рідини, полімер, математична модель, інтегральний реологічний закон, тензор напружень, функція пам'яті, чисельне інтегрування, квадратична інтерполяція, скінчено-різницевий метод, метод маркерів і комірок.

Introduction. The viscoelastic liquid may be a melt of a polymeric material from a rheological point of view. Therefore, emphasis will place on the practical application of the results of the solution of the mathematical model of the flow of viscoelastic fluid in the study of the process of filling the cavity of the mold with polymeric material.

High shear stresses can occur in flat or cylindrical channels. During the flow of viscoelastic fluid, in which the carbon bonds of macromolecules are broken, which leads to a decrease in the average molecular weight, and this leads to a change in molecular weight distribution, which significantly reduces the performance product. Therefore, it is important, in our opinion, to create a method for determining the stress field that arises in the process of forming products.

We know from [1] that if the energy required for the irreversible movement of macromolecules (melt flow) is significantly less than the energy of molecular bonds, then their rupture does not accompany the flow process. Thus, the calculation of stresses arising in the process of injection molding or extrusion at different design and technological parameters of this process is important for the design of equipment and equipment for injection molding and extrusion.

A large number of works is devoted to the determination of stresses that occur in different areas of the polymeric material during its flow through the channels [2-5] and when they fill with molds [6-8]. An analysis of research conducted by scientists showed that they assumed in the calculations that the stress at some point at a given time completely determined by the rate of deformation at the same point and at the same time. That is, the liquid does not remember what happened to it before. 
In this paper, it propose to introduce the concept of "memory" into the model and assume that the stress determine by the complete history of polymer deformation. This assumption is based on the theory of simple fluids with attenuating memory [9], from which it follows that the stress tensor can be expressed as an isotropic functional of the deformation history.

\section{Calculation of stresses within the flow region of the polymer melt}

Flow of a viscoelastic fluid with an integral rheological law consider in flat or cylindrical channels without narrowing (Fig. 1). We assume that in the plane case there is a Cartesian coordinate system $\mathrm{x}$, $\mathrm{y}$, and in the axisymmetric - a cylindrical coordinate system $\mathrm{x}, \mathrm{r}, \theta$.

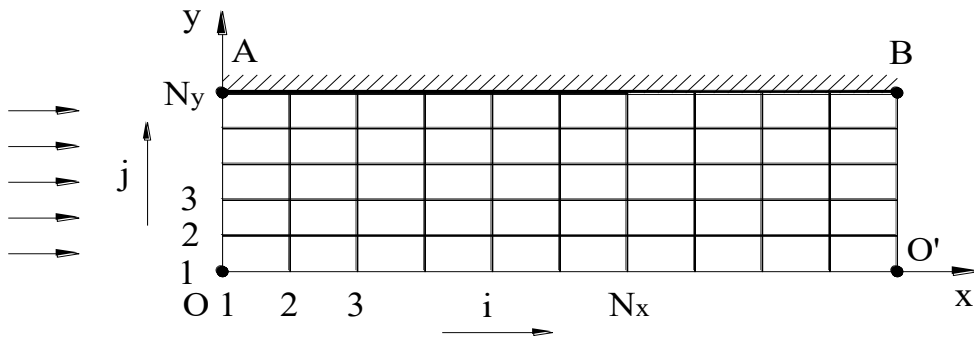

Fig. 1. Calculation grid

In the General case, enter the dimensionless parameter $\alpha$, which is equal to 0 for the flat case and 1 for the axisymmetric.

We choose a linear integral equation with relaxation as a rheological equation in dimensionless form:

$$
\tau^{i j}=\frac{1}{W^{2}} \int_{0}^{\infty} e^{-\frac{s}{W}} \cdot\left(F^{i j}-\delta^{i j}\right) d s
$$

where $\tau^{i j}$ - contravariant components of the stress tensor; $F^{i j} \equiv\left(C^{-1}\right)^{i j}$.

- contravariant components of the Finger tensor inverse to the Cauchy-Green tensor tensor $C$; $\delta^{i j}-$ unit tensor; $s$ - elapsed or elapsed time, defined as follows: $s=t-\bar{t} ; t$ - observation time; $\bar{t}-$ arbitrary moment of time, and $\bar{t}<t ; w=\lambda \cdot u_{0} / h$-dimensionless Weissenberg number; $u_{0}$ - component of the velocity vector at the input; $h$ - the half-width of the inlet channel, if the channel is rectangular, or $h=d_{s n} / 2$, if the inlet channel is cylindrical.

To calculate the components of the stress tensor within the region of the selected rheological equation (1) it is necessary to perform numerical integration. Since most rheological laws of the integral type of memory use exponents as a function, it is convenient to use the Lagger quadrature formula to calculate the integrals. [10].

Then, in our case, the value of the components of the stress tensor at a certain point in the region will calculate as follows:

$$
\tau^{i j}=\frac{1}{w^{2}} \int_{0}^{\infty} e^{-s / w} H^{i j} d s=\frac{1}{w} \int_{0}^{\infty} e^{-z} H^{i j} d z \approx \frac{1}{w} \sum_{k=1}^{N} A_{k} H^{i j}\left(z_{k}\right),
$$

де $z=s / w ; H^{i j}=F^{i j}-\delta^{i j} ; z_{k}$-interpolation points; $A_{k}$ - weights coefficients. Interpolation points and weights depend only on the number of interpolation points $N$. Thus, the strain tensor $H^{i j}$ is determined not at every step in time, but only in points $N$ interpolation $z_{k}(k=1,2, \ldots, N)$. Offset functions should be calculated at all intermediate points that are evenly distributed along the time axis. Each interval $\left(s_{i}, s_{i+1}\right)$ divide by an equal number of steps, for example, $P$. Then for each interval $\left(s_{i-1}, s_{i}\right)$ will be your time step $\Delta \bar{t}$.

$$
\Delta \bar{t}=\frac{P}{w}\left(z_{i}-z_{i-1}\right), \quad i=1,2, \ldots, N ; \quad z_{0}=0 .
$$

The value $P$ must satisfy the condition of stability [7], from which

$$
P \geq \frac{w\left(z_{i}-z_{i-1}\right)_{\max } 2 \sqrt{2} \max \{|u|,|v|\}}{h} .
$$

where $u, v$ - respectively, the horizontal and vertical components of the velocity vector.

From equation (4) it is seen that with increasing Weisenberg number the number of steps in time increases proportionally. Therefore, the errors in the definition $H^{i j}$ increase at large $P$ and may exceed the quadrature errors, resulting in high-order squaring does not make sense to use. Usually $N$ taken equal to two or three. 
Viscoelastic components of the stress tensor must calculate after calculating the components of the stress tensor, which are determined from the equations obtained in [7]. The central differences use to approximate the first derivatives of the velocities:

$$
\begin{aligned}
& \left(\tilde{\tau}^{x x}-\tilde{\tau}^{y y}\right)_{i, j}=\left(\tau^{x x}-\tau^{y y}\right)_{i, j}-\left(4 u_{x}^{\prime}+2 \alpha v / y\right)_{i, j}=\left(\tau^{x x}-\tau^{y y}\right)_{i, j}+\left[2\left(u_{i+1, j}-u_{i-1, j}\right)+2 \alpha v_{i, j} / y_{j}\right], \\
& \tilde{\tau}_{i, j}^{x y}=\tau_{i, j}^{x y}-\left(v_{x}^{\prime}+u_{y}^{\prime}\right)_{i, j}=\tau_{i, j}^{x y}-\frac{v_{i+1, j}-v_{i-1, j}+u_{i, j+1}-u_{i, j-1}}{2 h}, \\
& \left(\tilde{\tau}^{\theta \theta}-\tilde{\tau}^{r r}\right)_{i, j}=\left(\tau^{\theta \theta}-\tau^{r r}\right)_{i, j}-\left(2 u_{x}^{\prime}+4 \alpha v / r\right)_{i, j}=\left(\tau^{\theta \theta}-\tau^{r r}\right)_{i, j}-\left[\frac{u_{i+1, j}-u_{i-1, j}}{h}+\frac{4 \alpha v_{i, j}}{r_{j}}\right] .
\end{aligned}
$$

The last equation appears only in the cylindrical coordinate system.

Calculation of stresses on the wall. Tension $\tau^{x x}-\tau^{y y}, \tau^{x y}$ i $\tau^{\theta \theta}-\tau^{r r}$ calculate (the last difference only for cylindrical coordinates) on the wall in the absence of slippage, i.e. provided $u=v=0$. To do this, the components of the Finger tensor will need, which in turn depend on the shear functions determined from the system:

$$
\left.\begin{array}{l}
\bar{x}_{s}^{\prime}+u \cdot \bar{x}_{x}^{\prime}+v \cdot \bar{x}_{y}^{\prime}=0, \\
\bar{y}_{s}^{\prime}+u \cdot \bar{y}_{s}^{\prime}+v \cdot \bar{y}_{y}^{\prime}=0 .
\end{array}\right\}
$$

First of these equations differentiated by $x$, and then by $y$ and the following obvious ratios given : $\left(\bar{x}_{s}^{\prime}\right)_{x}^{\prime}=\left(\bar{x}_{x}^{\prime}\right)_{s}^{\prime}$ i $\quad\left(\bar{x}_{s}^{\prime}\right)_{y}^{\prime}=\left(\bar{x}_{y}^{\prime}\right)_{s}^{\prime} ; u\left(\bar{x}_{x}^{\prime}\right)_{y}^{\prime}=v\left(\bar{x}_{y}^{\prime}\right)_{x}^{\prime}=0 \quad$ (since $\left.u=v=0\right) ; \quad\left(u_{x}^{\prime}\right)_{s}^{\prime}=0$ (because there is stationarity); as well as due to the incompressibility of the fluid, so $u_{x}^{\prime}=-v_{y}^{\prime}$, a second order differential equation can be obtained for $\bar{x}_{x}^{\prime}$ :

$$
\left(\bar{x}_{x}^{\prime}\right)^{\prime \prime}-\beta^{2} \cdot \bar{x}_{x}^{\prime}=0
$$

where $\beta^{2}=\left(u_{x}^{\prime}\right)^{2}+v_{x}^{\prime} u_{y}^{\prime}$.

Solution of this equation taking into account the initial conditions: $\bar{x}=x$ for $s=0$, and $\bar{x}_{x}^{\prime}=1 \mathrm{i}$ $\left(\bar{x}_{x}^{\prime}\right)_{s}^{\prime}=-u_{x}^{\prime}$, looks like:

$$
\bar{x}_{x}^{\prime}(s)=-\frac{1}{\beta} u_{x}^{\prime} \operatorname{sh}(\beta s)+\operatorname{ch}(\beta s) .
$$

The expression for $\bar{x}_{y}^{\prime}$ will take this form:

$$
\bar{x}_{y}^{\prime}(s)=-\frac{1}{\beta} u_{y}^{\prime} \operatorname{sh}(\beta s) .
$$

Actions performing similar to the second equation (6), we obtain the following solution for the function $\bar{y}$ :

$$
\begin{aligned}
& \bar{y}_{x}^{\prime}(s)=-\frac{1}{\beta} v_{x}^{\prime} \operatorname{sh}(\beta s), \\
& \bar{y}_{y}^{\prime}(s)=-\frac{1}{\beta} u_{y}^{\prime} \operatorname{sh}(\beta s)+\operatorname{ch}(\beta s) .
\end{aligned}
$$

These solutions are valid for both Cartesian and cylindrical coordinate systems.

The components of the Finger tensor found according to [7] from the following relations:

$$
\begin{aligned}
& \left(C^{-1}\right)^{x x}=\frac{1}{\beta^{2}}\left[\left(u_{x}^{\prime}\right)^{2}+\left(u_{y}^{\prime}\right)^{2}\right] \cdot \operatorname{sh}^{2}(\beta s)+c h^{2}(\beta s)+\frac{1}{\beta} u_{x}^{\prime} \operatorname{sh}(2 \beta s), \\
& \left(C^{-1}\right)^{x y}=\frac{1}{2 \beta}\left(v_{x}^{\prime}+u_{y}^{\prime}\right) \cdot \operatorname{sh}(2 \beta s)-\frac{1}{\beta^{2}} u_{x}^{\prime}\left(u_{y}^{\prime}-v_{x}^{\prime}\right) \cdot \operatorname{sh}^{2}(\beta s), \\
& \left(C^{-1}\right)^{y y}=\frac{1}{\beta^{2}}\left[\left(u_{x}^{\prime}\right)^{2}+\left(v_{x}^{\prime}\right)^{2}\right] \cdot \operatorname{sh}^{2}(\beta s)+c h^{2}(\beta s)-\frac{1}{\beta} u_{x}^{\prime} \operatorname{sh}(2 \beta s) .
\end{aligned}
$$

Substituting these components in the rheological equation and conducting integration, we obtain: 


$$
\begin{aligned}
\tau^{x x} & =\frac{2}{1-4 \beta^{2} w^{2}}\left(u_{x}^{\prime}+w \cdot\left[u_{y}^{\prime} v_{x}^{\prime}+2\left(u_{x}^{\prime}\right)^{2}+\left(u_{y}^{\prime}\right)^{2}\right]\right), \\
\tau^{x y} & =\frac{2}{1-4 \beta^{2} w^{2}}\left(u_{y}^{\prime}+v_{x}^{\prime}+2 w \cdot\left(u_{y}^{\prime} v_{y}^{\prime}+u_{x}^{\prime} v_{x}^{\prime}\right)\right), \\
\tau^{y y} & =\frac{2}{1-4 \beta^{2} w^{2}}\left(-u_{x}^{\prime}+w \cdot\left[u_{y}^{\prime} v_{x}^{\prime}+2\left(u_{x}^{\prime}\right)^{2}+\left(v_{x}^{\prime}\right)^{2}\right]\right) .
\end{aligned}
$$

Finger tensor components $C_{x x}^{-1}, C_{x r}^{-1}, C_{r r}^{-1}$ in the cylindrical coordinate system differ from the components in the Cartesian system only by a factor $\bar{r} / r$. But the components $\tau$ calculate by formulas (12) in the absence of slippage on the wall, i.e. at $\bar{r}(x, r, s)=r$ or $\bar{r} / r=1$. Component $C_{\theta \theta}^{-1}=1$, that is $\tau_{\theta \theta}=0$.

Therefore, the components of the stress tensor on the solid wall with adhesion are obtained. If the walls coincide with the lines of the calculation grid, the expressions are significantly simplified. The calculations will use to calculate the stresses at a particular point.

Boundary conditions. Boundary conditions are necessary for solving the basic equations in the finitedifference form given in $[3,4]$, that is, for the flow function $\Phi$, vortex $\Theta$, and to calculate stresses and shear functions. In fig. 1 shows the main types of boundary cells used: horizontal and vertical solid walls, axis of symmetry, lines of entry and exit. Consider them separately.

Axis of symmetry_( $\left.1 \leq i \leq N_{x}, j=1\right)$.

The flow function and the vortex are zero on the axis of symmetry $\left(v=u_{x}^{\prime}=0\right)$ :

$$
\left.\begin{array}{l}
\Phi_{i, 1}=0, \\
\Theta_{i, 1}=0 .
\end{array}\right\} \quad i=1,2, \ldots, N_{x} .
$$

The expression can use for the modified vortex proposed in the paper [9]:

$$
\Theta_{i, 1}=\frac{8\left(\Phi_{i, 2}-\frac{\Phi_{i, 3}}{4}\right)}{3 h^{4}} .
$$

First, we calculate the Newtonian stresses to find the viscoelastic additives of the stress tensor. According to [7], they are equal to:

$$
\begin{aligned}
& \left(D^{x x}-D^{y y}\right)_{i, 1}=(4-\alpha) \cdot u_{x}^{\prime}=(4-\alpha) \frac{\left(u_{i+1,1}-u_{i-1,1}\right)}{2 h}, \\
& \left(D^{x y}\right)_{i, 1}=0, \quad i=1,2, \ldots, N_{x}, \\
& \left(D^{\theta \theta}-D^{r r}\right)_{i, 1}=0 .
\end{aligned}
$$

Components of the Finger tensor we find From equation (11) given that the following conditions are satisfied on the axis: $x_{y}^{\prime}=y_{x}^{\prime}=0 ; y_{y}^{\prime}=\bar{y} / y=1$ :

$$
\begin{aligned}
& \left(C^{-1}\right)^{x x}-\left(C^{-1}\right)^{y y}=1-\left(\bar{x}_{x}^{\prime}\right)^{2}, \\
& \left(C^{-1}\right)^{x y}=0, \\
& \left(C^{-1}\right)^{\theta \theta}-\left(C^{-1}\right)^{r r}=1-\left(\bar{x}_{x}^{\prime}\right)^{2} .
\end{aligned}
$$

If we know these values, the components of the stress tensor are determined using numerical integration, the procedure of which has described above. Viscoelastic additives has found as the difference between these and Newtonian stresses.

Speed $v$ on the axis of symmetry by definition is zero, as the derivative of the velocity is zero $u_{y}^{\prime}$. Speed $u$ find by quadratic interpolation:

$$
\left.\begin{array}{l}
u_{i, 1}=4 \frac{u_{i, 2}}{3}-\frac{u_{i, 3}}{3}, \\
v_{i, 1}=0
\end{array}\right\} \quad i=1,2, \ldots, N_{x}
$$

Output $\operatorname{section}_{-}\left(i=N_{x} ; 1 \leq j \leq N_{y}^{C}\right)$ : 
The condition is given by the equality of zero derivatives $\Phi$ i $\Theta$ at the output of the coordinate $x$ :

$$
\left.\begin{array}{l}
\Phi_{N_{x}, j}=\Phi_{N_{x}-1, j}, \\
\Theta_{N_{x}, j}=\Theta_{N_{x}-1, j} .
\end{array}\right\} \quad i=1,2, \ldots, N_{x} .
$$

Speed $u$ i $v$ are equal to:

$$
\left.\begin{array}{l}
u_{N, j}=\frac{1}{y^{\alpha}} \Phi_{y}^{\prime}=\frac{\left(\Phi_{N, j+1}-\Phi_{N, j-1}\right)}{2 h y^{\alpha}}, \\
v_{N, j}=0 .
\end{array}\right\} \quad j=2,3, \ldots, N_{y-1} .
$$

The output offset functions are equal to: $x^{\prime}=x-u_{y} s, y^{\prime}=y$. Then the components of the Finger tensor will look like this:

$$
\begin{aligned}
& \left(C^{-1}\right)^{x x}-\left(C^{-1}\right)^{y y}=\left(u_{y}^{\prime}\right)^{2} s^{2}, \\
& \left(C^{-1}\right)^{x y}=u_{y}^{\prime} s, \\
& \left(C^{-1}\right)^{\theta \theta}-\left(C^{-1}\right)^{r r}=0 .
\end{aligned}
$$

After integration, we find the rheological law:

$$
\begin{aligned}
& \tau^{x x}-\tau^{y y}=2 w\left(u_{y}^{\prime}\right)^{2}, \\
& \tau^{x y}=u_{y}^{\prime}, \\
& \tau^{\theta \theta}-\tau^{r r}=0 .
\end{aligned}
$$

Assuming that the Newtonian stresses are equal to: $D^{x x}-D^{y y}=0 ; D^{x y}=u_{y}^{\prime} ; D^{\theta \theta}-D^{r r}=0$, then the viscoelastic additives of the stress tensors on the wall will take this form:

$$
\begin{aligned}
& \left(\tilde{\tau}^{x x}-\tilde{\tau}^{y y}\right)_{N_{x}, j}=w \frac{u_{N_{x}, j+1}-u_{N_{x}, j-1}}{h^{2}}, \\
& \left(\tilde{\tau}^{x y}\right)_{N_{x}, j}=0 \\
& \left(\tilde{\tau}^{\theta \theta}-\tilde{\tau}^{r r}\right)_{N_{x}, j}=0 .
\end{aligned}
$$

At the point $\left(N_{x}, 1\right) u_{y}^{\prime}=0$, so $\widetilde{\tau}^{x x}-\widetilde{\tau}^{y y}=0$.

Wall parallel to the axis $\left(1 \leq i \leq N_{x}^{C} ; j=N_{y}\right.$ or $\left.N_{x}^{C} \leq i \leq N_{x} ; j=N_{y}^{C}\right)$.

The condition of sticking gives us

$$
u_{i, N_{y}}=0 ; \quad v_{i, N_{y}}=0 .
$$

The flow function is set equal to one

$$
\Phi_{i, N_{x}}=1 \text {. }
$$

Woods' formula of the second order of accuracy can use for a vortex on the wall [11]:

$$
\Theta_{i, N_{y}}=-\left[\frac{3\left(\Phi_{i, N_{y}-1}-\Phi_{i, N_{y}}\right)}{y_{N_{y}}^{2 \alpha} h^{2}}-\frac{\Theta_{i, N_{y}-1}}{2}\left(\frac{y_{N_{y}-1}}{y_{N_{y}}}\right)^{\alpha}\right] .
$$

The expressions for the components of the Finger stress tensors have the same form as for the previous case (20) and (22), except here $u_{y}^{\prime}=-\Theta \cdot y^{\alpha}$, that is, the first equation (22) will take the following form $\left(\tilde{\tau}^{x x}-\widetilde{\tau}^{y y}\right)_{i, N_{y}}=2 w\left(\Theta_{i, N_{y}} y_{N_{y}}^{\alpha}\right)^{2}$. The index $i$ gets the value from $N_{y}^{C}+1$ до $N_{y}$ for the wall CD. 
Wall perpendicular to the axis_( $\left.i=N_{x}^{C} ; N_{y}^{C} \leq j \leq N_{y}\right)$.

All boundary conditions are derived in exactly the same way as for a wall parallel to the axis, so we give only a summary of these expressions:

$$
\begin{aligned}
& u_{N_{x}^{C}, j}=0, \\
& v_{N_{x}^{C}, j}=0, \\
& \Phi_{N_{x}^{C}, j}=1, \\
& \Theta_{N_{x}^{C}, j}=-\left[\frac{3\left(\Phi_{N_{x}^{C}-1, j}-\Phi_{N_{x}^{C}, j}\right)}{y_{j}^{2 \alpha} h^{2}}-\frac{\Theta_{N_{x}^{C}-1, j}}{2}\left(\frac{y_{N_{y}-1}}{y_{N_{y}}}\right)^{\alpha}\right], \\
& \Theta_{N_{x}^{C}, N_{y}}=0, \\
& \left(\tilde{\tau}^{x x}-\tilde{\tau}^{y y}\right)_{N_{x}^{C}, j}=-2 w\left(\Theta_{N_{x}^{C}, j} y_{j}^{\alpha}\right)^{2}, \\
& \left(\tilde{\tau}^{x y}\right)_{N_{x}^{C}, j}=0, \\
& \left(\tilde{\tau}^{\theta \theta}-\tilde{\tau}^{r r}\right)_{N_{x}^{C}, j}=\left(\tilde{\tau}^{x x}-\tilde{\tau}^{y y}\right)_{N_{x}^{C}, j} .
\end{aligned}
$$

Entrance section_( $\left.i=1 ; j=1,2, \ldots, N_{y}\right)$.

We will set the speed $u$ at the entrance to the channel, corresponding to the Poiseuille flow for an inelastic liquid, i.e. the flow of a purely viscous liquid. Such solutions well known for many rheological laws.

The displacement functions, Newtonian stresses and viscoelastic additives calculate in the same way as for the initial section. They should only be replaced $N_{x}$ on 1 , and $N_{y}^{C}$ on $N_{y}$.

The equation must solve for the flow and vortex functions that derived in the paper [12]:

$$
\begin{aligned}
\Phi_{i, j}^{k+1}=(1-\omega) & \Phi_{i, j}^{k}+\frac{\omega}{4}\left[\Phi_{i+1, j}^{k}+\Phi_{i-1, j}^{k+1}+\Phi_{i, j+1}^{k} \cdot\left(1-\frac{\alpha \cdot h}{2 y_{j}}\right)+\Phi_{i, j-1}^{k+1} \cdot\left(1-\frac{\alpha \cdot h}{2 y_{j}}\right)+\Theta_{i, j}^{k} \cdot h^{2} y_{j}^{2 \alpha}\right], \\
\Theta_{i, j}^{k+1} & =(1-\omega) \cdot \Theta_{i, j}^{k}+\frac{\omega}{4}\left\{\left[\Theta_{i+1, j}^{k}+\Theta_{i-1, j}^{k+1}+\Theta_{i, j+1}^{k} \cdot\left(1-\frac{3 \alpha \cdot h}{2 y_{j}}\right)+\Theta_{i, j-1}^{k+1} \cdot\left(1-\frac{3 \alpha \cdot h}{2 y_{j}}\right)\right]-\right. \\
& -\frac{1}{y^{\alpha}}\left[\left(-\tilde{\tau}_{i+1, j}^{x y}-\tilde{\tau}_{i-1, j}^{x y}+\tilde{\tau}_{i, j+1}^{x y}\left(1-\frac{\alpha \cdot h}{2 y_{j}}\right)+\tilde{\tau}_{i, j-1}^{x y}\left(1-\frac{\alpha \cdot h}{2 y_{j}}\right)-\frac{\alpha \tilde{\tau}_{i, j}^{x y}}{y_{j}^{2}}\right)+\right. \\
& +\frac{1}{4}\left(\left(\tilde{\tau}^{x x}-\tilde{\tau}^{y y}\right)_{i+1, j+1}-\left(\tilde{\tau}^{x x}-\tilde{\tau}^{y y}\right)_{i+1, j-1}-\left(\tilde{\tau}^{x x}-\tilde{\tau}^{y y}\right)_{i-1, j+1}+\left(\tilde{\tau}^{x x}-\tilde{\tau}^{y y}\right)_{i-1, j-1}\right)+ \\
+ & \left.\left.\frac{\alpha \cdot h}{2 y_{j}}\left(\left(\tilde{\tau}^{\theta \theta}-\tilde{\tau}^{y y}\right)_{i+1, j}-\left(\tilde{\tau}^{\theta \theta}-\tilde{\tau}^{y y}\right)_{i-1, j}\right)\right]^{k}\right\}
\end{aligned}
$$

where $k$-iteration number.

Thus the fictitious (zero) number of knots should be entered in the direction of an axis. We will accept fictitious values in these nodes $\widetilde{\Phi} \mathrm{i} \widetilde{\Theta}$ according to such formulas:

$$
\left.\begin{array}{l}
\widetilde{\Phi}_{0, j}=\widetilde{\Phi}_{2, j}=\Phi_{1, j}, \\
\widetilde{\Theta}_{0, j}=\widetilde{\Theta}_{2, j}=\Theta_{1, j} .
\end{array}\right\} \quad j=2,3, \ldots, N_{y-1} .
$$

Note that all parts in (28) that have contain additives $\widetilde{\tau}$ fall out. Value $\Phi$ i $\Theta$ set in points $(1,1)$ i $\left(1, N_{y}\right)$, both on the axis of symmetry and as on a solid horizontal wall. The system of the obtained equations solved by the iterative method of successive relaxation.

This fact must note. Calculations made for the inlet and outlet boundaries are valid only in the case of a sufficient distance of the narrowing of the pipe from the inlet and outlet. The larger the Weissenberg number and the closer to the input and output the narrowing is located, the more the real boundary conditions will differ from the values obtained by these formulas, as in this case the condition will be practically not fulfilled. $\Phi_{x}^{\prime}=\Theta_{x}^{\prime}=0$. In 
the break of the flow lines, it manifeste most clearly at the entrance and exit. Since the condition of smoothness violate, the calculated trajectories of the particles (which can be constructed knowing the shear functions) will not coincide with the flow lines. Because of this, errors may appear in the calculation of the components of the Finger tensor.

Corner point $\left(i=N_{x}^{C} ; j=N_{y}^{C}\right)$.

As for the rest of the wall, the following equations will be true:

$$
\begin{aligned}
& u_{N_{x}^{C}, N_{y}^{C}}=v_{N_{x}^{C}, N_{y}^{C}}=0, \\
& \Phi_{N_{x}^{C}, N_{y}^{C}}=1 .
\end{aligned}
$$

Kawaguchi method use to find the vortex and the components of the stress tensor, in which when calculating the derivatives of the flow function at an angular point are introduced its fictitious values at the boundaries [13]:

$$
\begin{aligned}
& \widetilde{\Phi}_{N_{x+1}^{C}, N_{y}^{C}}=\Phi_{N_{x-1}^{C}, N_{y}^{C}}, \\
& \widetilde{\Phi}_{N_{x}^{C}, N_{y+1}^{C}}=\Phi_{N_{x}^{C}, N_{y-1}^{C}}, \\
& \widetilde{\Phi}_{N_{x+1}^{C}, N_{y+1}^{C}}=\Phi_{N_{x-1}^{C}, N_{y-1}^{C}} .
\end{aligned}
$$

Then according to [7] and taking into account $u=\Phi_{r}^{\prime} / r=0$ we will receive

$$
\Theta_{N_{x}^{C}, N_{y}^{C}}=-\frac{\Phi_{x}^{\prime \prime}+\Phi_{y}^{\prime \prime}}{y^{2 \alpha}}=-2 \frac{\Phi_{N_{x-1}^{C}, N_{y}^{C}}+\Phi_{N_{x}^{C}, N_{y-1}^{C}}}{y_{N_{y}^{C}}^{2} h^{2}} .
$$

Such expressions may take place for viscoelastic additives:

$$
\left.\begin{array}{l}
\tilde{\tau}^{x x}-\widetilde{\tau}^{y y}=\frac{2}{1-4 \beta^{2} w^{2}}\left(w \cdot\left[\left(u_{y}^{\prime}\right)^{2}-\left(v_{x}^{\prime}\right)^{2}\right]+16 \beta^{2} w^{2} u_{x}^{\prime}\right), \\
\tilde{\tau}^{x y}=\frac{2}{1-4 \beta^{2} w^{2}}\left[2 w \cdot\left(u_{y}^{\prime} v_{y}^{\prime}+u_{x}^{\prime} v_{x}^{\prime}\right)+4 \beta^{2} w^{2}\left(u_{y}^{\prime}+v_{x}^{\prime}\right)\right], \\
\tilde{\tau}^{\theta \theta}-\tilde{\tau}^{r r}=-\frac{2}{1-4 \beta^{2} w^{2}}\left[w \cdot\left(u_{y}^{\prime} v_{x}^{\prime}+2\left(u_{y}^{\prime}\right)^{2}+\left(v_{x}^{\prime}\right)^{2}\right)+8 \beta^{2} w^{2} u_{x}^{\prime}\right]
\end{array}\right\}
$$

Derivatives of velocities in the Kawaguchi method can be determined from the following equations:

$$
\begin{aligned}
& \left.u_{x}^{\prime}\right|_{N_{x}^{C}, N_{y}^{C}}=\left.\frac{\Phi_{x}^{\prime \prime}}{y^{\alpha}}\right|_{N_{x}^{C}, N_{y}^{C}}=\frac{2 \Phi_{N_{x-1}^{C}, N_{y-1}^{C}}-\Phi_{N_{x-1}^{C}, N_{y+1}^{C}}-\Phi_{N_{x+1}^{C}, N_{y-1}^{C}}}{4 h^{2} y_{N_{y}^{C}}^{\alpha}}, \\
& \left.u_{y}^{\prime}\right|_{N_{x}^{C}, N_{y}^{C}}=\left.\frac{\Phi_{y}^{\prime \prime}}{y^{\alpha}}\right|_{N_{x}^{C}, N_{y}^{C}}=\frac{2\left(\Phi_{N_{x}^{C}, N_{y-1}^{C}}-\Phi_{N_{x}^{C}, N_{y}^{C}}\right)}{h^{2} y_{N_{y}^{C}}^{\alpha}}, \\
& \left.v_{x}^{\prime}\right|_{N_{x}^{C}, N_{y}^{C}}=\left.\frac{\Phi_{x}^{\prime \prime}}{y^{\alpha}}\right|_{N_{x}^{C}, N_{y}^{C}}=\frac{2\left(\Phi_{N_{x}^{C}, N_{y}^{C}}-\Phi_{N_{x-1}^{C}, N_{y}^{C}}\right)}{h^{2} y_{N_{y}^{C}}^{\alpha}}, \\
& \left.v_{y}^{\prime}\right|_{N_{x}^{C}, N_{y}^{C}}=-\left.u_{x}^{\prime}\right|_{N_{x}^{C}, N_{y}^{C}} .
\end{aligned}
$$

Calculations. The procedure for calculating the flow of a viscoelastic fluid of integral form consists of the following computational steps:

1. Newtonian solution looking for an iteration of equations (27) and (28) in which viscoelastic additives assume to be zero. The fields of the flow and vortex functions are the zero approximation for the first iteration in finding the viscoelastic solution.

2. The components of the velocity vector and their derivatives by coordinates are calculated using difference formulas of the second order of accuracy According to the known flow function within the region. Here the components of the Newtonian stress tensor are calculated.

3 . Velocity limits, flow, vortex and viscoelastic additives are determined.

4. Shift functions $\bar{x}$ i $\bar{y}$ determined at the boundary and within the region by a known field of velocities

5. Derivatives are in the coordinates of the shift function at the interpolation points on the axis of dimensionless time $s$. 
6. The components of the excess stress tensor sought at the interpolation points in the region and on the axis.

7. Viscoelastic components of the stress tensor found as the difference of the tensors of excess and Newtonian stresses.

8. Equation (28) solve for the vortex, resulting in its new values. The boundary conditions containing the vortex from the flow region correct and the equation for the vortex solve again.

9. Equation (27) solve for the current function with new vortex values.

10. If the relative magnitude of the difference between the old and new values of the flow and vortex functions exceed some small value $\varepsilon$, then all calculations are repeated again from the second point and so on until acceptable accuracy achieved.

The proposed higher computational procedure has programmed and tested to solve two problems: a) the speed of viewing in a flat tube without sound and at the rod current at the inlet; b) the same, but with a Poiseuille velocity profile at the entrance to the pipe.

As a result, of solving the first problem, the velocity field and the steady-state voltage compare at the outlet of the tube for Newtonian () and viscoelastic (with different) fluids with an analytical solution of the problem, which has the form:

$$
\begin{aligned}
& u=u_{0}\left(1-y^{2}\right), v=0 \\
& D^{x x}-D^{y y}=0, \quad D^{x y}=u_{y}^{\prime}=-2 u_{0} y \text {; } \\
& \tau^{x x}-\tau^{y y}=2 w\left(u_{y}^{\prime}\right)^{2}=8 w \cdot u_{0}^{2} y^{2}, \quad \tau^{x y}=u_{y}^{\prime}=-2 u_{0} y .
\end{aligned}
$$

The first problem was solved for a Newtonian fluid with unit dimensionless viscosity and a viscoelastic fluid with Weissenberg numbers equal to: 0,$001 ; 0,1 ; 0,5$. Calculations have shown that for viscoelastic fluid even at maximum number $w=0,5$ the velocity field is very slightly different from the Newtonian. In fig. 2 shows the stress distribution, which shows that the greater $w$, the slower the current goes to steady state and the greater the difference in normal voltages.
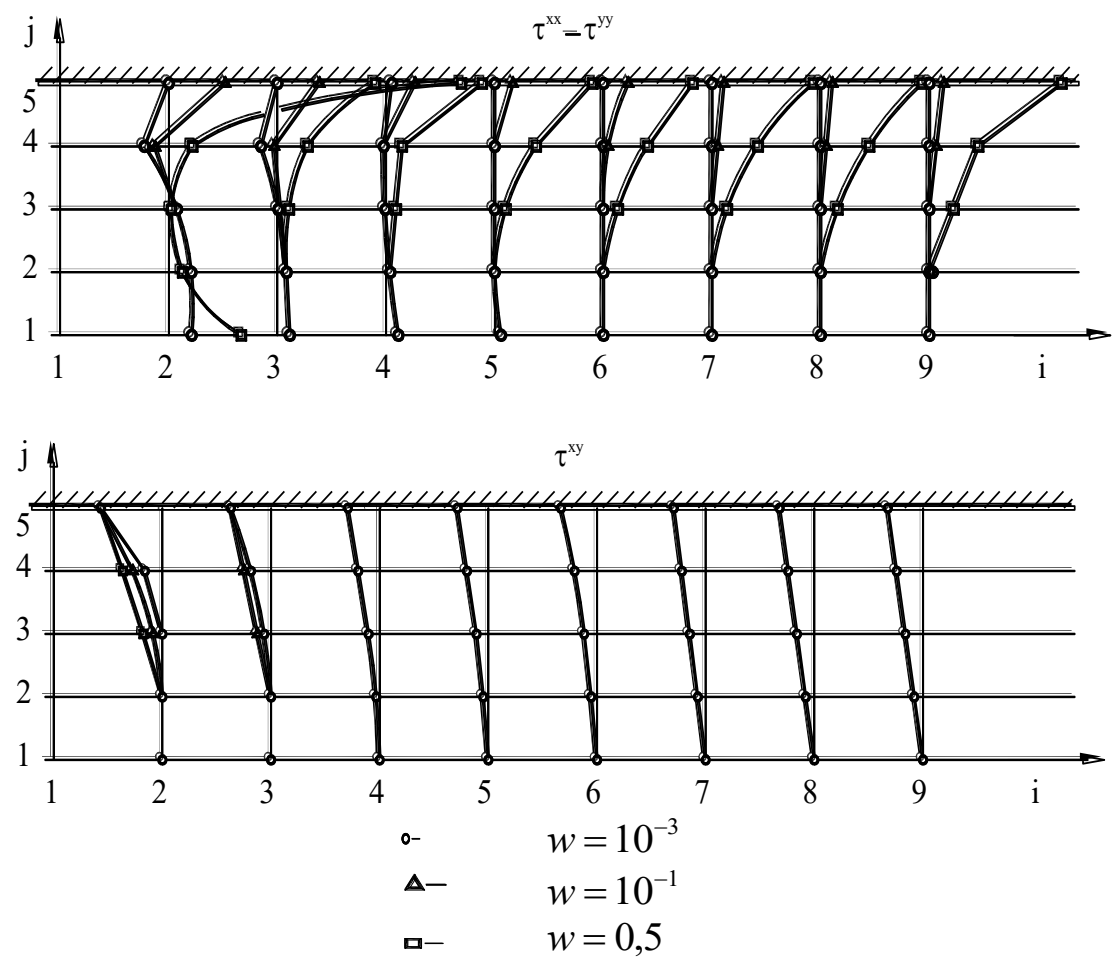

Fig. 2. Normal and tangential stresses during the flow of the polymer melt in a flat inlet $(i=9, j=5)$

At $w=10^{-3}$ both normal and tangential stresses almost coincide with Newtonian $(w=0)$.

Particle trajectories were also calculated (back in time) taken in different zones of the flow region: at the inlet boundary, near the inlet, in the center of the region, near the outlet, and at the outlet. The discrepancy between the trajectories of the particles and the current lines were observed only in the inlet region, and the discrepancy is greater the steeper the fracture of the flow line. This can explaine by the fact that the Lax-Wendroff procedure for calculating the shear functions requires the smoothness of the velocity field, which is violated at the input boundary at points near the solid walls. 
The second test problem is more convenient and clear to check the accuracy of the resulting solution, because it is easy to check its correctness: all calculated values should not change in the direction of the coordinate $x$ with accuracy $\varepsilon$, with which the whole system of finite-difference equations is solved. Figures 3 ,a and 3 ,b show an almost complete coincidence of numerical and analytical solutions.
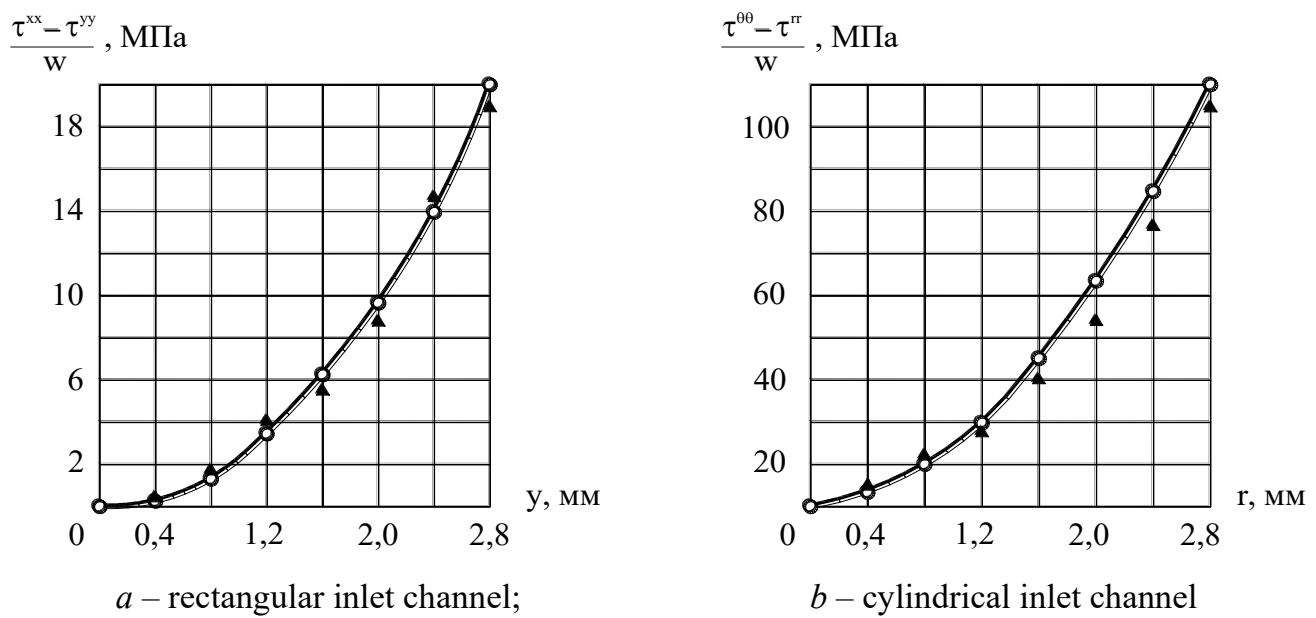

Fig. 3. Comparison of the solution obtained by the finite-difference method ( $i=15, j=8, w=10^{-1}$ ), with analytical

०- results of the analytical solution; - - the results of the solution by the finite-difference method of markers and cells

Conclusions. High shear stresses can occur during the flow of viscoelastic fluid in flat or cylindrical channels, which break the carbon bonds of macromolecules. This leads to a decrease in the average molecular weight and to a change in the molecular weight distribution, which significantly reduces the performance of the finished product. Therefore, in our opinion, it is important to create a method for determining the field of shear stresses, which will determine the allowable shear stresses at which the carbon bonds will not break.

The paper introduces the concept of "memory", i.e. it has assumed that the stress has determined by the complete history of polymer deformation. This assumption is based on the theory of simple fluids with attenuating memory, from which it follows that the stress tensor can be expressed as an isotropic functional of the prehistory of deformation.

Numerical mathematical model of viscoelastic fluid flow Developed in flat or cylindrical channels when implementing its finite difference method (MAC method) and allows determining the stress field in the middle of the entire region of viscoelastic fluid flow. The calculation procedure has proposed by the finite difference method to solve the developed numerical model of the flow of a viscoelastic fluid with an integral rheological law.

The results of this modeling can use in the development of injection molding and improvement of equipment for injection molding of polymer manufacturers.

Comparing the solutions obtained by finite-different methods with analytical and testing of the programmed mathematical model. It is possible to draw a conclusion about the correctness of the stated formula, developed algorithms and program.

\section{References}

1. Basov N. I., Kazankov Yu. V. Litevoe formovanie polimerov, - M.: Himiya, 1984.

2. Tadmor Z. Teoreticheskie osnovyi pererabotki polimerov. / Z. Tadmor, K. Gogos. -M. : Himiya, 1984. - $632 \mathrm{~s}$.

3. Zlotenko B.M., Skyba M.Ye., Synyuk O.M. Metod markeriv i komirok u zadachax ruxu ridyn z vilnoyu poverxneyu // Visnyk Texnologichnogo universytetu Podillya. - 1999. - \# 6. - S. 142-144.

4. Zlotenko B.N., Skyba N.E., Synyuk O.M. Konechno-raznostnыj metod y`ssledovany`ya processa zapolneny`ya pryamougol`noj pressformy putem vyzualyzacyi potoka rasplava // Visnyk Kyyivskogo derzhavnogo universytetu texnologij ta dyzajnu. - 2000. - \# 2. - S. 48 - 53.

5. Ossvald T.A. Lite plastmass pod. davleniem / T.A. Ossvald, L.-Sh. Tung, P.Dzh. Gremann; pod red. E. L. Kalincheva. - SPb. : Professiya, 2006. $-712 \mathrm{~s}$.

6. Zlotenko B. M. Naukovi osnovy proektuvannya tekhnolohichnoho protsesu lyttya vyrobiv lehkoyi promyslovosti z prohnozovanymy vlastyvostyamy : Avtoref. dys ... d-ra tekhn. nauk : 05.19 .06 / B. M. Zlotenko; V.o. Kyyiv. nats. un-t tekhnolohiy ta dyzaynu. K. : B.v., 2003.- $36 \mathrm{~s}$.

7. Berezin I. K., Levina G. V. Metodyi rascheta techeniy so svobodnyimi granitsami // Reologicheskie svoystva polimernyih sistem. Sverdlovsk, 1979. - 1979. - S. 20-28.

8. Kulik T. I. Vdoskonalennya tekhnolohichnoho protsesu lyttya kombinovanykh vzuttyevykh vyrobiv iz polimernykh materialiv / T. I. Kulik // Dys... kand. tekhn. nauk. - 2006. - 190 s.

9. Astarita Dzh., Maruchchi Dzh. Osnovyi gidromehaniki nenyutonovskih zhidkostey. - M.: Mir, 1981. - 310 s.

10. Korn G., Korn T. Spravochnik po matematike dlya nauchnyih rabotnikov. - M.: Nauka, 1977. - $720 \mathrm{~s}$.

11. Gosmen A. D., Pan V. M., Ranchel A. K. i dr. Chislennyie metodyi issledovaniya techeniy vyazkoy zhidkosti. - M.: Mir, 1972. - 324 s.

12. Samarskiy A. A. Teoriya raznostnyih shem. - M.: Nauka, 1983. - $616 \mathrm{~s}$.

13. Rouch P. Vyichislitelnaya gidrodinamika. - M.: Mir, 1980. - $420 \mathrm{~s}$. 